\title{
ANALISIS KLASTER: KARAKTERISTIK, KANDUNGAN ZAT GIZI, DAN SENYAWA AKTIF EXTRA VIRGIN OLIVE OIL DI SUPERMARKET
}

\author{
Cluster Analysis: Characteristic, Nutrient Content, and Active Compound \\ of Extra Virgin Olive Oil in Supermarket
}

\author{
Retno Mardhiati ${ }^{*}$, Sri Anna Marliyati², Drajat Martiano², Siti Madanijah², I Wayan T Wibawan ${ }^{3}$ \\ ${ }^{1}$ Program Studi Kesehatan Masyarakat, Fakultas IImu-IImu Kesehatan, \\ Universitas Muhammadiyah Prof. Dr. Hamka \\ Jalan Limau II, Kebayoran Baru, Jakarta Selatan, DKI Jakarta, Indonesia \\ ${ }^{2}$ Departemen Gizi Masyarakat, Fakultas Ekologi Manusia, Institut Pertanian Bogor \\ Jalan Dramaga, Bogor, Jawa Barat, Indonesia \\ 3Departemen Ilmu Penyakit Hewan dan Kesmasvet, Fakultas Kedokteran Hewan, \\ Institut Pertanian Bogor \\ Jalan Dramaga, Bogor, Jawa Barat, Indonesia \\ *e-mail: retno_ma@uhamka.ac.id
}

Submitted : February $24^{\text {th }}, 2020$, revised : May 23 2 rd 2021 , approved: May $27^{\text {th }}, 2021$

\begin{abstract}
Background. Nutrient contents of extra virgin olive oil (EVOO) possess abundant benefits for human's health. Some of them function as immunomodulator, preventing heart disease and other vascular diseases, preventing allergic diseases, improving liver's function, and avoiding other diseases. The EVOO's nutrient contents in different EVOO brands are not identical since they are determined by many factors. Objective. This study aimed to do cluster analysis, based on their chemical characteristic, nutrient content, and active compound of seven product samples of EVOO supplied in supermarket. Method. Descriptive design was used in this study. The collection of seven EVOO product samples from supermarkets in Great Jakarta area was done in March 2019. The EVOO product samples examination was performed in Bogor at The Center of Agro Based Industry Laboratory of Ministry of Industry and Biofarmaka, laboratory of Institute for Research and Community Service Bogor Agricultural University. Analysis used in this study was cluster analysis with hierarchical method approach. Result. Based on chemical characteristic, it was found that EVOO product sample $6^{\text {th }}$ had the most different chemical characteristic. EVOO product sample $4^{\text {th }}$ contained the most different unsaturated fatty acid content whereas unsaturated acid content of sample $1^{\text {st }}, 3^{\text {rd }}$, and $7^{\text {th }}$ were similar. The vitamin $E$ content of EVOO product sample $2^{\text {nd }}$ and the iron content of EVOO product sample $6^{\text {th }}$ were different from other samples. Total flavonoid content of EVOO product sample $2^{\text {nd }}$, $3^{\text {rd }}$, and $4^{\text {th }}$ were similar. Total carotenoid content of EVOO product sample $2^{\text {nd }}$ and $6^{\text {th }}$ were also comparable. Conclusion. The chemical characteristics of all EVOO product samples found in the study had almost the same value.The EVOO product samples from supermarket supplies possess differences on unsaturated fatty acid, total flavonoid, and carotenoid content.
\end{abstract}

Keywords: fatty acid, Fe, flavonoid, olive oil, vitamin E

\footnotetext{
ABSTRAK

Latar Belakang. Kandungan zat gizi extra virgin olive oil (EVOO) memiliki banyak manfaat untuk kesehatan manusia. Beberapa manfaat antara lain sebagai imunomodulator, mencegah penyakit jantung dan vaskuler lainnya, mencegah penyakit alergi, memperbaiki fungsi liver, dan mencegah penyakit lainnya. Kandungan zat gizi tiap merek EVOO tidak sama, ditentukan oleh banyak faktor. Tujuan. Penelitian ini bertujuan menganalisis klaster berdasarkan karakteristik kimiawi, kandungan zat gizi, dan senyawa aktif pada tujuh sampel produk EVOO dari supermarket. Metode.
} 


\begin{abstract}
Desain deskriptif digunakan dalam penelitian ini. Pengumpulan tujuh sampel produk EVOO di supermarket wilayah Daerah Khusus Ibukota (DKI) Jakarta dilakukan pada bulan Maret 2019. Pemeriksaan sampel produk EVOO dilakukan di Laboratorium Balai Besar Industri Agro (BBIA) Kementerian Perindustrian dan Laboratorium Biofarmaka dan Lembaga Penelitian Pengabdian Masyarakat (LPPM) Institut Pertanian Bogor (IPB). Analisis yang digunakan adalah analisis klaster melalui pendekatan hierarchical method. Hasil. Berdasarkan karakteristik kimiawi, ditemukan bahwa sampel produk EVOO ke-6 memiliki karakteristik kimiawi paling berbeda. Sampel produk EVOO ke-4 memiliki kandungan asam lemak jenuh paling berbeda. Kandungan asam lemak tak jenuh pada sampel produk EVOO ke-1, 3, dan 7 mendekati kesamaan. Kandungan vitamin E pada sampel produk EVOO ke-2 dan kandungan zat besi pada sampel produk EVOO ke-6, berbeda dengan sampel produk EVOO lainnya. Kandungan total flavonoid pada sampel produk EVOO ke-2, 3, dan 4, memiliki kadar mendekati kesamaan. Kandungan total karotenoid pada sampel produk EVOO ke-2 dan ke-6 juga memiliki kadar mendekati kesamaan. Kesimpulan. Karakteristik kimiawi pada semua sampel produk EVOO yang ditemukan dalam penelitian memiliki nilai hampir sama. Sampel produk EVOO di supermarket memiliki perbedaan kandungan asam lemak tak jenuh, total flavonoid, dan total karotenoid.
\end{abstract}

Kata kunci: asam lemak, zat besi, flavonoid, minyak zaitun, vitamin E

\section{PENDAHULUAN}

Extra virgin olive oil (EVOO) merupakan minyak dari buah zaitun yang diperas secara mekanis dan tidak mengalami perubahan pada minyak serta tidak ada penambahan kimiawi kecuali perlakuan pencucian, dekantansi, sentrifugasi, dan filtrasi. Karena dihasilkan dari perasan pertama tanpa proses kimia dan tanpa penyulingan, maka EVOO merupakan minyak zaitun dengan kualitas terbaik. Namun kualitas kandungan zat gizi dalam produk EVOO sangat dipengaruhi oleh proses pengepakan, penyimpanan, dan pendistribusian. ${ }^{1}$ Penetapan standar EVOO secara internasional mengacu pada standar yang dikeluarkan oleh International Olive Council (IOC), Codex Alimentarius Commission (CAC), United States Department of Agriculture (USDA), California Department of Food and Agriculture (CDFA), dan standar Uni Eropa. Kelima lembaga internasional tersebut menetapkan EVOO memiliki tingkat keasaman tidak lebih dari $0,8 \mathrm{~g}$ dari $100 \mathrm{~g}$. Spanyol (40\%), Italia (21\%), dan Yunani (13\%), dikenal sebagai wilayah yang paling banyak memproduksi minyak zaitun di dunia. Indonesia mengimpor EVOO terbanyak dari Italia, Spanyol, dan Turki. ${ }^{2}$

Masyarakat memilih EVOO sebagai salah satu cara untuk meningkatkan dan memelihara kesehatan. ${ }^{3,4}$ Kelemahan penggunaan EVOO sebagai suplemen kesehatan yaitu harga yang lebih mahal dibandingkan dengan suplemen kesehatan yang terbuat dari tumbuhan herbal lokal. EVOO termasuk bahan makanan fungsional karena mengandung zat gizi serta memiliki senyawa makronutrien dan mikronutrien yang dapat memberikan efek fisiologis spesifik untuk kesehatan. Selain itu EVOO memenuhi syarat sebagai makanan fungsional karena telah terbukti secara ilmiah memiliki takaran dan keamanan konsumsi, memiliki klaim kesehatan, dan penyajiannya berbeda dengan produk obatobatan. EVOO mengandung senyawa yang dapat memengaruhi fungsi tubuh dan memberikan efek fungsional dengan menurunkan risiko timbulnya penyakit. Secara ilmiah EVOO dapat mencegah penyakit jantung dan kerusakan membran sel, melindungi pencernaan, tulang dari osteoporosis, sistem endokrin tubuh, dapat menyembuhkan luka, dan berperan sebagai 
antikanker, antiinflamasi, antimikroba dan virus, serta imunomodulator. ${ }^{2,5,6,7}$

Kandungan zat gizi mayor EVOO berbentuk asam lemak. Kandungan asam lemak tak jenuh dalam EVOO berkaitan dengan kesehatan tubuh. Kandungan zat gizi minor EVOO berkisar 1-3 persen yang terdiri dari vitamin, mineral, dan senyawa aktif seperti fenolik. ${ }^{2}$ Vitamin $E$ merupakan salah satu kandungan zat gizi minor dalam EVOO yang berperan dalam regenerasi sel. Kandungan vitamin $E$ memiliki fungsi sebagai antioksidan yang dapat mencegah oksidasi nonenzimatik komponen sel. Kekuatan EVOO sebagai antiinflamasi disebabkan oleh kandungan vitamin $\mathrm{E}$ yang sangat lengkap dalam bentuk tokoferol (tipe $\alpha, \beta, \gamma, \delta$ ). ${ }^{8}$ Tokoferol merupakan antioksidan paling penting. Dalam darah terdapat 90 persen vitamin $\mathrm{E}$ dalam bentuk tokoferol- $\alpha$ dan 10 persen dalam bentuk tokoferol- $\gamma .^{9}$

EVOO digunakan sebagai antiinflamasi karena memiliki kandungan flavonoid yang berfungsi melindungi struktur sel. ${ }^{8}$ Kualitas EVOO juga ditentukan oleh kandungan zat besi (Fe), flavonoid, dan karotenoid beserta beberapa zat bioaktif seperti hydroxytyrosol, tyrosol, oleuropein, oleochantal, dan squalene. Namun kandungan zat bioaktif dalam EVOO sulit terdeteksi karena jumlah zat sangat kecil. ${ }^{10}$

Informasi kandungan zat gizi pada produk EVOO di Indonesia masih sangat minim. Kandungan asam oleat, vitamin E, dan senyawa bioaktif dalam produk EVOO berkaitan dengan peningkatan daya tahan tubuh. ${ }^{11}$ Kandungan asam oleat merupakan asam lemak tertinggi dalam EVOO. Informasi kandungan zat gizi dalam produk EVOO menjadi dasar pemilihan produk. Profil kandungan zat gizi dalam produk EVOO juga berkaitan dengan varietas pohon zaitun, proses panen dan pascapanen, pengemasan, pendistribusian, dan penyimpanan. Data profil produk EVOO dengan kandungan asam oleat, vitamin $\mathrm{E}$, dan senyawa bioaktif terbanyak dapat menjadi pertimbangan untuk mendapatkan produk yang berkualitas.

Penelitian ini bertujuan untuk menganalisis karakteristik kimiawi, kandungan zat gizi, dan senyawa aktif pada tujuh sampel produk EVOO dari supermarket dengan menggambarkan data dan informasi profil produk EVOO, serta menganalisis kemiripan atau perbedaan profil produk dengan analisis klaster.

\section{METODE}

Penelitian ini mengambil tujuh sampel produk EVOO yang tersedia di supermarket wilayah DKI Jakarta dengan sampling nonprobabilitas. Penelitian ini hanya mengambil satu produk untuk setiap merek produk EVOO yang tersedia di supermarket, dengan batas kedaluwarsa pada tahun yang sama. Karakteristik kimiawi produk EVOO yang diteliti meliputi bilangan iod, asam dan penyabunan, kadar air, serta abu. Zat gizi yang diteliti meliputi asam lemak, vitamin $\mathrm{E}$, zat besi, total flavonoid, dan total karotenoid. Semua sampel produk EVOO diperiksa di Laboratorium Balai Besar Industri Agro (BBIA) Kementerian Perindustrian dan Laboratorium Biofarmaka dan Lembaga Penelitian Pengabdian Masyarakat (LPPM) Institut Pertanian Bogor (IPB) pada bulan Maret tahun 2019.

Pengujian sampel yang berkaitan dengan karakteristik kimiawi EVOO 1998 (bilangan asam, bilangan iod, bilangan penyabunan, dan kadar air) dilakukan sesuai dengan Standar Nasional Indonesia (SNI) 01-3555-1998. Metode pemeriksaan kadar abu sesuai dengan SNI 01- 
2891-1992. Pemeriksaan kadar asam lemak dilakukan dengan metode gas chromatography (GC) sesuai dengan International Union of Pure and Applied Chemistry (IUPAC) metode 2.301. Pemeriksaan total flavonoid dan total karotenoid menggunakan teknik spektrofotometer. Pemeriksaan vitamin E dilakukan dengan high performance liquid chromatography (HPLC). Pemeriksaan zat besi dilakukan dengan metode Association of Official Analytical Chemist (AOAC) 999.11. Bahan dan alat yang digunakan sesuai dengan standar prosedur yang akan dilakukan. Analisis data dilakukan dengan analisis deskriptif dan analisis klaster hierarki. Analisis klaster hierarki menunjukkan produk-produk EVOO di supermarket memiliki perbedaan atau kemiripan karakteristik dan kandungan zat gizi. Nomor sampel yang terakhir bergabung dalam dendogram merupakan sampel produk EVOO dengan karakteristik dan kandungan zat gizi paling berbeda. Analisis klaster hierarki merupakan analisis yang mengelompokkan, diukur berdasarkan jarak antara produk EVOO satu dengan produk EVOO lainnya. Semakin jauh jarak produk, kemiripan semakin tidak ada. Penelitian ini merupakan bagian dari penelitian intervensi EVOO pada hewan coba. Etik Penelitian diperoleh dari Komisi Etik Hewan LPPM IPB Bogor nomor 142-2019 IPB tanggal 3 Mei 2019.

\section{HASIL}

Tabel 1 menunjukkan semua sampel produk EVOO yang diambil dalam penelitian memiliki karakteristik kimia sesuai dengan standar. Kadar air memiliki kemiripan pada semua sampel produk EVOO. Kadar abu tertinggi 0,04 persen pada sampel produk EVOO ke-3 dan ke-6 tetapi kadar abu tidak terdeteksi pada sampel lainnya.

Tabel 1. Karakteristik Tujuh Sampel Produk EVOO di Supermarket Wilayah DKI Jakarta

\begin{tabular}{|c|c|c|c|c|c|c|c|c|}
\hline Kriteria & $\begin{array}{c}\text { IOC } \\
2017^{12}\end{array}$ & $\begin{array}{c}\text { Produk } \\
\text { EVOO } \\
1\end{array}$ & $\begin{array}{c}\text { Produk } \\
\text { EVOO } \\
2\end{array}$ & $\begin{array}{c}\text { Produk } \\
\text { EVOO } \\
3\end{array}$ & $\begin{array}{c}\text { Produk } \\
\text { EVOO } \\
4\end{array}$ & $\begin{array}{c}\text { Produk } \\
\text { EVOO } \\
5\end{array}$ & $\begin{array}{c}\text { Produk } \\
\text { EVOO } \\
6\end{array}$ & $\begin{array}{c}\text { Produk } \\
\text { EVOO } \\
7\end{array}$ \\
\hline Air (\%) & - & 0,13 & 0,13 & 0,13 & 0,12 & 0,13 & 0,13 & 0,12 \\
\hline Abu (\%) & - & 0,02 & 0,01 & 0,04 & 0,01 & 0,02 & 0 & 0,03 \\
\hline $\begin{array}{l}\text { Bilangan asam } \\
(\mathrm{mg} \mathrm{KOH} / \mathrm{g})\end{array}$ & $<0,8$ & 0,59 & 0,49 & 0,55 & 0,54 & 0,61 & 0,59 & 0,56 \\
\hline $\begin{array}{l}\text { Bilangan iod } \\
(\mathrm{mg} / 100 \mathrm{~g})\end{array}$ & $75-94$ & 81,3 & 81,6 & 82,2 & 83,9 & 81,6 & 83,3 & 82,8 \\
\hline $\begin{array}{l}\text { Bilangan penyabunan } \\
(\mathrm{mg} \mathrm{KOH} / \mathrm{g})\end{array}$ & 184-196 & 191 & 190 & 190 & 190 & 191 & 192 & 189 \\
\hline
\end{tabular}


Tabel 2 menunjukkan sampel produk EVOO dalam penelitian ini memiliki kadar asam palmitat 10,2-13,6 persen dan kadar asam stearat 3,0-5,45 persen. Kadar asam laurat dan asam miristat terdeteksi hanya pada dua sampel produk EVOO. Asam lemak tak jenuh pada sampel produk EVOO memiliki kandungan asam oleat $72,7-74,7$ persen, asam linoleat 7,27-9,18 persen, dan kadar asam linolenat $0,81-2,41$ persen. Tidak semua sampel produk EVOO memiliki kandungan asam lemak sesuai standar. $^{12}$

Tabel 2. Kandungan Asam Lemak (\%) Tujuh Sampel Produk EVOO di Supermarket Wilayah DKI Jakarta

\begin{tabular}{|c|c|c|c|c|c|c|c|c|}
\hline Kriteria & $\begin{array}{c}\text { IOC } \\
2017^{12}\end{array}$ & $\begin{array}{c}\text { Produk } \\
\text { EVOO } \\
1\end{array}$ & $\begin{array}{c}\text { Produk } \\
\text { EVOO } \\
2\end{array}$ & $\begin{array}{c}\text { Produk } \\
\text { EVOO } \\
3\end{array}$ & $\begin{array}{c}\text { Produk } \\
\text { EVOO } \\
4\end{array}$ & $\begin{array}{c}\text { Produk } \\
\text { EVOO } \\
5\end{array}$ & $\begin{array}{c}\text { Produk } \\
\text { EVOO } \\
6\end{array}$ & $\begin{array}{c}\text { Produk } \\
\text { EVOO } \\
7\end{array}$ \\
\hline \multicolumn{9}{|l|}{ Lemak jenuh } \\
\hline Total asam laurat & - & 0 & 0 & 0 & 0,29 & 0 & 0,05 & 0 \\
\hline Total asam miristat & $\leq 0,03$ & 0 & 0 & 0 & 0,24 & 0 & 0,08 & 0 \\
\hline Total asam palmitat & $7,5-20$ & 10,4 & 10,5 & 10,6 & 10,2 & 10,4 & 13,6 & 10,4 \\
\hline Total asam stearat & $0,5-5$ & 5,45 & 5,29 & 3,57 & 4,14 & 4,31 & 3,00 & 3,65 \\
\hline \multicolumn{9}{|l|}{ Lemak tak jenuh } \\
\hline Total asam oleat & $55-83$ & 72,7 & 74,3 & 73,6 & 74,5 & 74,7 & 72,9 & 72,9 \\
\hline Total asam linoleat & $2,5-21$ & 8,31 & 7,48 & 9,18 & 7,65 & 7,65 & 7,27 & 8,95 \\
\hline Total asam linolenat & $0-1$ & 1,65 & 1,42 & 1,84 & 1,91 & 1,63 & 0,81 & 2,41 \\
\hline
\end{tabular}

Gambar 1 menunjukkan dari tujuh sampel terdapat enam sampel produk EVOO yang memiliki kemiripan kandungan asam lemak jenuh. Terlihat dalam gambar dendogram, sampel ke-4 bergabung terakhir dalam dendogram. Kadar asam lemak jenuh yang terdeteksi dalam pemeriksaan antara lain kadar asam laurat, asam miristat, asam palmitat, dan asam stearat. Kandungan asam lemak tak jenuh pada enam sampel produk EVOO menunjukkan produk ke-4, 5, dan 2 memiliki kemiripan kandungan asam lemak tak jenuh dan membentuk menjadi satu klaster, sedangkan klaster lainnya terbentuk dari kemiripan kandungan asam lemak pada produk ke-3, 7, dan 1. Sampel produk ke-6 lebih mirip pada klaster satu. Berdasarkan kandungan asam lemak tak jenuh, sampel-sampel produk EVOO lebih berbeda dibandingkan dengan kandungan asam lemak jenuh. 


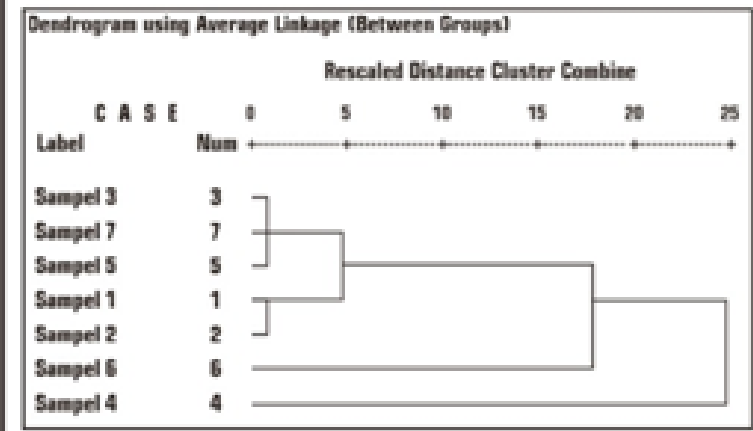

a. Asam Lemak Jenuh

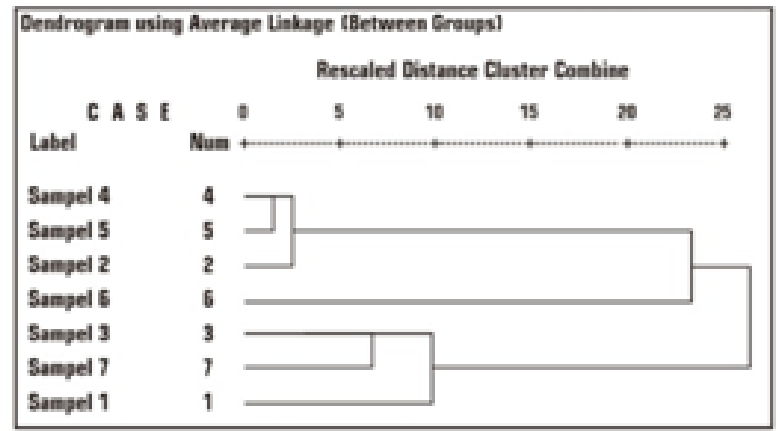

a. Asam Lemak Tak Jenuh

Gambar 1. Sampel Produk EVOO Berdasarkan Kandungan Asam Lemak Jenuh dan Asam Lemak Tak Jenuh pada Tujuh Sampel Produk EVOO di Supermarket Wilayah DKI Jakarta

Tabel 3 menunjukkan kadar vitamin E yang ditemukan dalam penelitian ini berkisar 11,6$24,7 \mathrm{mg} / \mathrm{kg}$ dan kandungan zat besi berkisar
0,23-11,8 $\mathrm{mg} / \mathrm{kg}$. Kadar total flavonoid semua produk EVOO berkisar 0,02-0,45 persen (b/b) dan kadar karotenoid berkisar 11,5-20,9 mg/kg.

Tabel 3. Kandungan Vitamin E, Zat Besi, Total Flavonoid, dan Total Karotenoid pada Tujuh Sampel Produk EVOO di Supermarket Wilayah DKI Jakarta

\begin{tabular}{lccccccc}
\hline \multicolumn{1}{c}{ Kriteria } & $\begin{array}{c}\text { Produk } \\
\text { EVOO } \\
\end{array}$ & $\begin{array}{c}\text { Produk } \\
\text { EVOO }\end{array}$ & $\begin{array}{c}\text { Produk } \\
\text { EVOO }\end{array}$ & $\begin{array}{c}\text { Produk } \\
\text { EVOO } \\
4\end{array}$ & $\begin{array}{c}\text { Produk } \\
\text { EVOO } \\
5\end{array}$ & $\begin{array}{c}\text { Produk } \\
\text { EVOO } \\
6\end{array}$ & $\begin{array}{c}\text { Produk } \\
\text { EVOO }\end{array}$ \\
\hline Vitamin E (mg/kg) & 18 & 11,6 & 23,1 & 17,4 & 20,6 & 19,3 & 24,7 \\
Zat besi (mg/kg) & 0,23 & 0,16 & 0,25 & 0,82 & 1,12 & 11,8 & 0,39 \\
$\begin{array}{l}\text { Total flavonoid } \\
\text { \%(b/b) }\end{array}$ & 0,33 & 0,03 & 0,02 & 0,03 & 0,36 & 0,26 & 0,45 \\
$\begin{array}{l}\text { Total karotenoid } \\
(\mathrm{mg} / \mathrm{kg})\end{array}$ & 20,4 & 11,5 & 20,9 & 17,4 & 25,2 & 11,9 & 17,9 \\
\hline
\end{tabular}

Pada Gambar 2, hasil dendogram menunjukkan sampel produk EVOO ke-1 dan ke-4 memiliki kemiripan kandungan vitamin $E$. Sampel produk EVOO ke-5 memiliki kandungan vitamin E mirip dengan sampel produk EVOO ke-6, sedangkan kandungan vitamin E sampel produk EVOO ke-3 mirip dengan sampel produk EVOO ke-7. Sampel produk EVOO ke-2 memiliki perbedaan dibandingkan dengan sampelsampel lainnya, yaitu kandungan vitamin E yang 
lebih rendah. Berdasarkan kandungan zat besi terdapat kemiripan pada sampel produk EVOO ke-1, 2, 3, 4, dan 5. Berdasarkan kandungan total flavonoid, terdapat kemiripan pada sampel produk EVOO ke-1, 2, 3, 4, 5, dan 7. Berdasarkan kandungan total karotenoid, terdapat kemiripan pada sampel produk EVOO ke-2 dan ke-4, sampel produk EVOO ke-3 dan ke-1, dan sampel produk EVOO ke-5 dan ke-6. Hanya sampel produk EVOO ke-7 yang tidak memiliki kemiripan dengan sampel produk EVOO lainnya karena memiliki kandungan karotenoid paling tinggi.

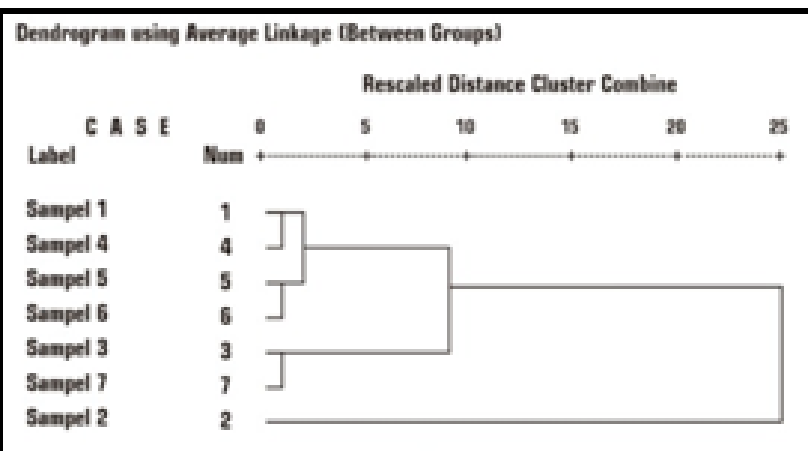

a. Kandungan Vitamin E

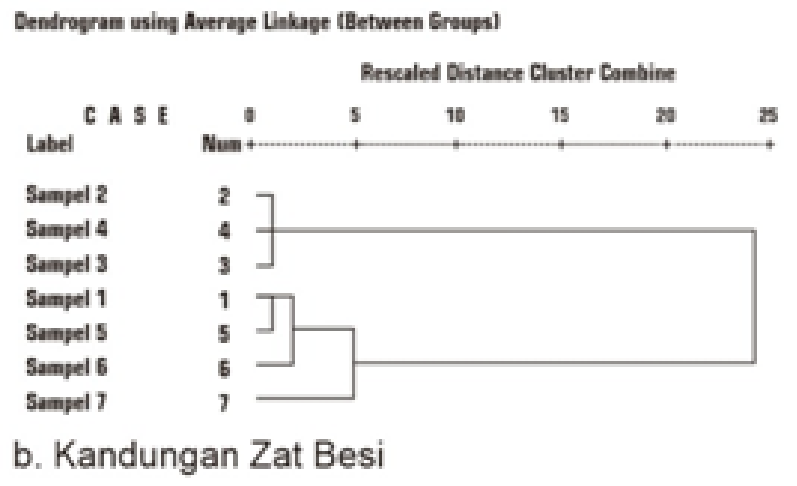

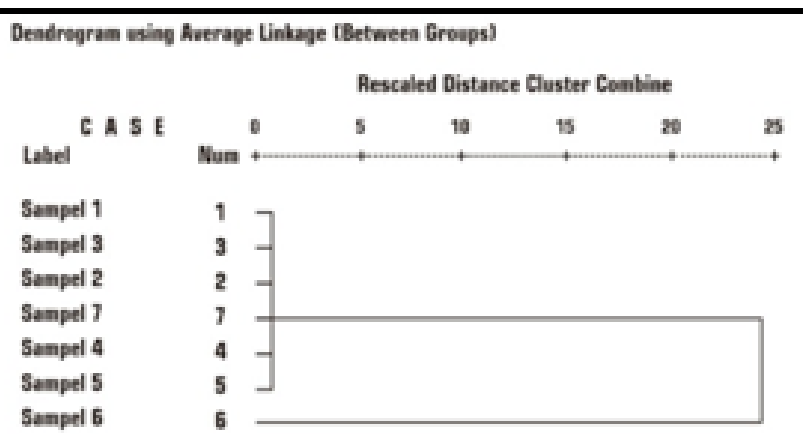

c. Kandungan Total Flavonoid

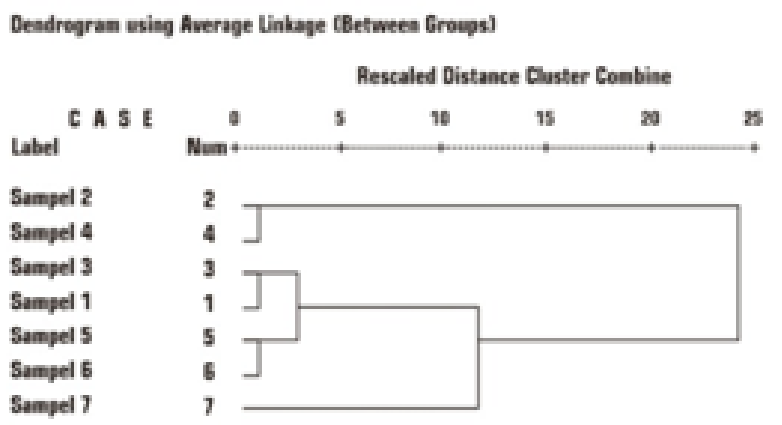

d. Kandungan Total Karotenoid

Gambar 2. Sampel Produk EVOO Berdasarkan Kandungan Vitamin E, Zat Besi, Total Flavonoid, dan Total Karotenoid

\section{PEMBAHASAN}

Beberapa karakteristik EVOO menunjukkan kualitas dan pemenuhan standar EVOO. Kualitas EVOO dapat dilihat dari profil kadar air, kadar abu, dan beberapa bilangan seperti iod, penyabunan, dan asam. Kadar air yang rendah dapat mencegah reaksi hidrolisis. ${ }^{13}$ Kadar abu menunjukkan residu dari komponen anorganik atau mineral yang tersisa setelah proses pembakaran. Semakin besar kadar abu suatu pangan, kandungan anorganik dalam suatu zat semakin besar. ${ }^{14}$ Hasil penelitian menunjukkan kadar bilangan asam pada sampel produk EVOO dari supermarket berkisar antara 0,49-0,61 mg $\mathrm{KOH} / \mathrm{g}$, masih di bawah ambang batas bilangan asam sebesar $1 \mathrm{mg} \mathrm{KOH} / \mathrm{g}$. Hasil penelitian ini tidak berbeda jauh dengan penelitian lain yang menemukan bilangan penyabunan sebesar $192,1 \mathrm{mg} \mathrm{KOH} / \mathrm{g}$, bilangan iod berkisar 88,2 $\mathrm{mg} / \mathrm{g}$, dan bilangan asam $0,38 \mathrm{mg} \mathrm{KOH} / \mathrm{g}^{15}$ Bilangan penyabunan pada EVOO asal Turki paling tinggi dibandingkan dengan minyak mustard, rapeseed (rapa), bunga matahari, dan kacang. Sebaliknya, bilangan iod pada 
EVOO asal Turki paling rendah dibandingkan dengan minyak mustard, rapeseed (rapa), bunga matahari, dan kacang. ${ }^{16}$ Semua produk EVOO yang menjadi sampel penelitian ini memenuhi standar karakteristik minyak zaitun yang ditetapkan.

Minyak zaitun, minyak kedelai, dan minyak kanola lebih banyak diproduksi dari negara lain, tetapi mudah diakses di Indonesia. Minyak lain yang juga mengandung asam lemak tak jenuh tunggal dan mudah diakses di Indonesia antara lain minyak kacang tanah dan minyak biji kapas. ${ }^{17}$ Komponen mayor EVOO terdiri dari asam oleat, asam palmitat, asam linoleat, asam strearat, asam palmitoleat, asam linolenat, dan asam miristat. ${ }^{18}$ Kandungan asam lemak tak jenuh tunggal atau monounsaturated fatty acid (MUFA) yang memiliki ikatan rangkap satu buah pada rantai atom karbon pada EVOO dinyatakan dalam persen. EVOO juga mengandung asam lemak tak jenuh ganda atau polyunsaturated fatty acids (PUFA) yakni asam linoleat dan asam linolenat. Dalam metabolisme tubuh, MUFA lebih efektif daripada PUFA untuk menurunkan kadar kolesterol, lebih stabil, dan lebih baik perannya dalam meningkatkan highdensity lipoprotein (HDL) dan menurunkan low-density lipoprotein (LDL). PUFA banyak ditemukan pada minyak ikan, minyak safflower, minyak jagung, dan minyak biji matahari. Fungsi PUFA antara lain mengatur tekanan darah, fungsi jantung, fungsi kekebalan tubuh, transform metabolisme lemak, fungsi imun, mempertahankan fungsi integritas membran sel, dan meningkatkan rangsangan saraf. ${ }^{17}$ PUFA memiliki turunan yakni asam arakidonat (asam linoleat), asam eikosapentaenoat (EPA), dan asam dokosaheksaenoat (DHA).
Hasil penelitian ini menunjukkan sebagian besar produk EVOO memenuhi standar untuk asam lemak jenuh dan asam lemak tak jenuh. Hampir semua produk memiliki kandungan total asam linolenat di atas jumlah standar EVOO. Produk EVOO dalam sampel penelitian ini memiliki kemiripan kandungan asam lemak tak jenuh, tetapi terdapat dua sampel yang memiliki perbedaan pada kandungan asam lemak jenuh. Kadar asam oleat dalam sampel produk EVOO penelitian ini hampir sama dengan hasil temuan beberapa penelitian lain. Hal ini menunjukkan proses pengepakan dan pengemasan produk EVOO cukup baik, sehingga produk EVOO tetap memiliki kandungan asam oleat sesuai standar.

Adanya kemiripan atau kesamaan antara sampel produk EVOO dalam penelitian ini juga ditemukan dalam penelitian lainnya. Penelitian lain menunjukkan kadar asam oleat pada sampel EVOO sebesar 65-83 persen..$^{19,20}$ Dalam $100 \mathrm{~g}$ EVOO terdapat MUFA 73,7 g, SFA 13,5 g, PUFA 7,9 g. ${ }^{21}$ Komposisi asam lemak dari produk EVOO asal Calabria, Italia antara lain palmitat (C16:0) sebesar 14,56-14,90 persen, palmitoleat $(\mathrm{C} 16: 1)$ sebesar $1,03-1,49$ persen, margarik (C17:0) sebesar 0,04-0,16 persen, stearat (C18:0) sebesar 1,90-2,33 persen, oleat (C18:1) sebesar 66,09-74,44 persen, linoleat (C18:2) sebesar 6,11-14,59 persen, linolenat (C18:3) sebesar 0,42-0,63 persen, asam arakidat (C20:0) sebesar 0,08-0,11 persen, total asam lemak jenuh sebesar 13,3 persen, total asam lemak tak jenuh tunggal sebesar 81,6 persen, dan total asam lemak tak jenuh ganda sebesar 5,08 persen. ${ }^{22}$ Beberapa merek EVOO dari Italia menunjukkan kandungan asam linoleat pada Luccese $(9,53 \%)$, Blanqueta $(7,15 \%)$, Agrocreta (7,35\%) dan asam linolenat 
Luccese (0,25\%), Blanqueta (0,29\%), Agrocreta $(0,27 \%) .{ }^{23}$

EVOO memiliki salah satu komponen minor yakni komponen fenol yang terdiri dari komponen lipofilik seperti tokoferol dan tokotrienol. Sedangkan komponen hidrofilik meliputi asam fenol, secoiridoids, lignin, dan flavonoid. ${ }^{18}$ Kandungan vitamin $\mathrm{E}$ dalam EVOO paling lengkap dan lebih tinggi dibandingkan dengan minyak nabati lainnya. ${ }^{24}$ Vitamin $E$ merupakan antioksidan yang larut dalam lemak dan lebih efektif meredakan radikal bebas dibandingkan dengan antioksidan lain. Dosis konsumsi vitamin E bagi orang dewasa sebesar 8-10 IU per hari. Vitamin E mampu mengakhiri proses reaksi berantai radikal bebas dengan menghambat produksi radikal bebas baru dan membatasi perusakan sampai batas area membran sel. Antioksidan dalam EVOO yang paling utama berbentuk tokoferol- $\alpha$. Kandungan tokoferol- $\alpha$ berbeda sesuai dengan wilayah geografis buah zaitun. Kandungan tokoferol- $\alpha$ dari Turki varietas Queslati (156-252 mg/kg) dan Chemlali (100-188 mg/kg). Kandungan tokoferol- $\alpha$ berkaitan dengan stabilitas oksidatif. Semakin tinggi kandungan tokoferol- $\alpha$ maka semakin stabil. ${ }^{25}$ Kandungan tokoferol- $\alpha$ EVOO Albania dan Coffu ditemukan sebesar 47,39 mg/ $\mathrm{kg}$ dan $158,54 \mathrm{mg} / \mathrm{kg}$, lebih tinggi dari sampel penelitian ini. ${ }^{26}$ Produk EVOO dari Italia memiliki kandungan tokoferol- $\delta$ sebesar $0,48 \pm 0,19 \mathrm{mg} /$ $\mathrm{kg}$, kandungan tokoferol- $\gamma$ sebesar 2,93 $\pm 0,4$ $\mathrm{mg} / \mathrm{kg}$, dan kandungan tokoferol- $\alpha$ sebesar $122,37 \pm 2,33 \mathrm{mg} / \mathrm{kg} .{ }^{27}$ Kandungan produk EVOO dari Sardinia Italia di Villacidro (tokoferol- $\alpha$ 172,2 $\mathrm{mg} / \mathrm{kg}$ dan tokoferol- $\gamma 15,3 \mathrm{mg} / \mathrm{kg}$ ), di Cagliari (tokoferol- $\alpha$ 159,3 $\mathrm{mg} / \mathrm{kg}$ dan tokoferol- $\gamma$ 8,8 $\mathrm{mg} / \mathrm{kg}$ ), di Semidana (tokoferol- $\alpha 181,5 \mathrm{mg} /$ $\mathrm{kg}$ dan tokoferol- $\gamma 9,1 \mathrm{mg} / \mathrm{kg}$ ), dan di Basana (tokoferol- $\alpha$ 213,3 $\mathrm{mg} / \mathrm{kg}$ dan tokoferol- $\gamma$ $8,7 \mathrm{mg} / \mathrm{kg}$ ). ${ }^{28}$ Kandungan Vitamin $\mathrm{E}$ sekitar 0-37 mg dari $100 \mathrm{~g}$ EVOO, diperkirakan memenuhi kebutuhan sekitar 72-96 persen. ${ }^{29}$

Keberagaman kandungan vitamin $\mathrm{E}$ dalam EVOO berdasarkan varietas dan wilayah. Dalam penelitian ini kandungan vitamin $\mathrm{E}$ sampel produk EVOO antara 11,6-24,7 mg/kg. Kandungan karotenoid dalam minyak zaitun asal Turki varietas Queslati $(1,74 \mathrm{mg} / \mathrm{kg})$ dan varietas Chemlali $(1,63 \mathrm{mg} / \mathrm{kg})$, sementara dalam penelitian ini berkisar 11,5-25,2 mg/ $\mathrm{kg}$. Proses pengolahan EVOO menentukan besaran kandungan karotenoid. ${ }^{25}$ Total karotenoid dari produk EVOO Italia berkisar 4,20-4,62 mg/kg. ${ }^{27}$ Kandungan total karotenoid pada EVOO asal Turki lebih tinggi dari minyak bunga matahari dan minyak kacang. ${ }^{16}$ Hasil penelitian ini menunjukkan kandungan total karotenoid dalam sampel produk EVOO lebih tinggi dibandingkan dengan hasil penelitian lain. Kandungan karotenoid memengaruhi warna EVOO. Kandungan vitamin E, kadar Fe, dan jumlah total flavonoid serta kadar karotenoid berkaitan dengan fungsi imun tubuh. ${ }^{11}$

\section{KESIMPULAN}

Karakteristik kimiawi (kadar air, abu, bilangan iod, bilangan penyabunan, dan bilangan asam) pada semua sampel produk EVOO yang ditemukan dalam penelitian memiliki nilai hampir sama. Terdapat variasi kandungan asam stearat dan asam lemak linoleat pada sampel penelitian dengan kandungan asam linoleat tertinggi 9,18 persen pada sampel produk EVOO ke-3. Kandungan tertinggi vitamin $\mathrm{E}$ sebesar $23,1 \mathrm{mg} / \mathrm{kg}$, zat besi $11,8 \mathrm{mg} / \mathrm{kg}$, total flavonoid 
0,45 persen (b/b), total karotenoid $25,2 \mathrm{mg} / \mathrm{kg}$. Sampel produk EVOO ke-7 memiliki kandungan flavonoid tertinggi. Dalam penelitian ini, kualitas sampel produk EVOO terbaik memiliki kandungan asam oleat, total flavonoid, dan total karotenoid tertinggi.

\section{UCAPAN TERIMA KASIH}

Ucapan terima kasih disampaikan kepada Lembaga Penelitian dan Pengembangan Universitas Muhammadiyah Prof. Dr. Hamka, Pusat Kajian Kesehatan Fakultas IImu-IImu Kesehatan Universitas Muhammadiyah Prof. Dr. Hamka, dan semua pihak yang telah mendukung pelaksanaan penelitian.

\section{DAFTAR PUSTAKA}

1. Jabeur $H$, Zribi A, Bouaziz M. Changes in Chemical and Sensory Characteristics of Chemlali Extra-Virgin Olive Oil as Depending on Filtration. European Journal of Lipid Science and Technology. 2017;119(1):1-10.

2. Trade Data International. Sample File - Indonesia Imports of Virgin Olive Oil. Diunduh dari: https://tradedata.net/wpcontent/uploads/2020/11/SAMPLE-FILEIndonesian-imports-Virgin-Olive-Oil.pdf

3. Gorzynik-Debicka M, Przychodzen P, Cappello F, Kuban-Jankowska A, Gammazza AM, Knap N, et al. Potential Health Benefits of Olive Oil and Plant Polyphenols. Int J Mol Sci. 2018;19(3):1-13.

4. De Santis S, Cariello M, Piccinin E, Sabbà C, Moschetta A. Extra Virgin Olive Oil: Lesson from Nutrigenomics. Nutrients. 2019;11(9):2085.
5. Gaforio JJ, Visioli F, de la Lastra CA, Castañer O, Delgado-Rodríguez M, Fitó M, et al. Review Virgin Olive Oil and Health: Summary of the III International Conference on Virgin Olive Oil and Health Consensus Report, JAEN (Spain) 2018. Nutrients. 2019;11(9):2039.

6. Omar SH. Plant Review Olive: Native of Mediterranean Region and Health Benefits. Pharmacognosy Review. 2008;2(3):135-42.

7. Al-Waili NS. Clinical and Mycological Benefits of Topical Application of Honey, Olive Oil and Beeswax in Diaper Dermatitis. Clin Microbiol Infect. 2005;11(2):160-3.

8. Amiot MJ. Olive Oil and Health Effects: From Epidemiological Studies to The Molecular Mechanisms of Phenolic Fraction. Oilseeds \& Fats Crops \& Lipids. 2014;21(5):1-8.

9. Muchtadi D. Pangan Fungsional dan Senyawa Bioaktif. Bandung: Alfabeta; 2012.

10. Borges TH, Pereira JA, Cabrera-Vique C, Seiquer I. Study of the Antioxidant Potential of Arbequina Extra Virgin Olive Oils from Brazil and Spain Applying Combined Models of Simulated Digestion and Cell Culture Markers. Journal of Functional Foods. 2017;37:209-18.

11. Baratawidjaja KG, Rengganis I. Imunologi Dasar. Jakarta: Badan Penerbit Fakultas Kedokteran Universitas Indonesia; 2014.

12. International Olive Council. Trade Standard Applying to Olive Oils And Olive Pomace Oils. Madrid: International Olive Council; 2019.

13. Sumarna D. Studi Metode Pengolahan Minyak Sawit Merah (Red Palm Oil) dari 
Crude Palm Oil (CPO). Prosiding Seminar Kimia; 2014.

14. Sunartaty R, Yulia R. Pembuatan Abu dan Karakteristik Kadar Air dan Kadar Abu dari Abu Pelepah Kelapa. Prosiding Seminar Nasional II Universitas Serambi Mekah; 24 Agustus 2017; Aceh;2007. p. 560-2.

15. Chaiyana W, Leelapornpisid P, Phongpradist $\mathrm{R}$, Kiattisin K. Enhancement of Antioxidant and Skin Moisturizing Effects of Olive Oil by Incorporation into Microemulsions. Nanomaterials and Nanotechnology. 2016;6:1-8.

16. Konuskan DB, Arslan M, Oksuz A. Physicochemical Properties of Cold Pressed Sunflower, Peanut, Rapeseed, Mustard and Olive Oils Grown in the Eastern Mediterranean Region. Saudi Journal of Biological Sciences. 2019;26:340-4.

17. Sartika RAD. Pengaruh Asam Lemak Jenuh, Tidak Jenuh dan Asam Lemak Trans terhadap Kesehatan. KESMAS, Jurnal Kesehatan Masyarakat Nasional. 2008;2(4):154-60.

18. Granados-Principal S, Quiles JL, RamirezTortosa CL, Sanchez-Rovira P, RamirezTortosa MC. Hydroxytyrosol: From Laboratory Investigations to Future Clinical Trials. Nutrition Reviews. 2010;68(4):191206.

19. Orsavova J, Misurcova L, Ambrozova JV, Vicha R, Mlcek J. Fatty Acids Composition of Vegetable Oils and Its Contribution to Dietary Energy Intake and Dependence of Cardiovascular Mortality on Dietary Intake of Fatty Acids. Int J Mol Sci. 2015;16(6):1287190.
20. Peri C. The Extra-Virgin Olive Oil Handbook. UK:John Wiley \& Sons, Ltd; 2014.

21. Assy N, Nassar F, Nasser G, Grosovski M. Olive Oil Consumption and Non-Alcoholic Fatty Liver Disease. World J Gastroenterol. 2009;15(15):1809-15.

22. Piscopo A, De Bruno A, Zappia A, Ventre C, Poiana M. Characterization of Monovarietal Olive Oils Obtained from Mills of Calabria Region (Southern Italy). Food Chemistry. 2016;213:313-8.

23. Kráčmar $S$, Fišera $M$, Přikrylová $V$, Fišerová L, Málek Z, Tvrzník P. Storage of Extra Virgin Olive Oil and Its Impact on Fatty Acid Levels. J Microbiol Biotech Food Sci. 2019;8(5):1228-30.

24. Winarti S. Makanan Fungsional. Jakarta: Graha IImu; 2010.

25. Fares N, Jabri IK, Sifi S, Abderrabba M. Physical Chemical and Sensory Characterization of Olive Oil of the Region of Kairouan. J Mater Environ Sci. 2016;7(6):2148-54.

26. Demertzi KA, Roukos C, Demertzis P. Basic Characteristics and Quality of Virgin Olive Oil Produced in Corfu (cv. Lianolia) and South Albania (cv. Kalinioti). International Journal of Scientific Research and Management. 2018;6(3):16-32.

27. Sanmartin C, Taglieri I, Macaluso M, Sgherri C, Ascrizzi R, Flamini G, et al. Cold-Pressing Olive Oil in the Presence of Cryomacerated Leaves of Olea or Citrus: Nutraceutical and Sensorial Features. Molecules. 2019;24(14):2625. 
28. Tuberoso CIG, Jerkovic I, Maldini M, Serreli G. Phenolic Compounds, Antioxidant Activity, and Other Characteristics of Extra Virgin Olive Oils from Italian Autochthonous Varieties Tonda di Villacidro, Tonda di Cagliari,
Semidana, and Bosana. Journal of Chemistry. 2016;8462741.

29. Mazzocchi A, Leone L, Agostoni C, PaliSchöll I. The Secrets of the Mediterranean Diet. Does [Only] Olive Oil Matter? Nutrients. 2019;11(12):2941. 